\title{
New species of symbiotic scaleworms Asterophilia (Polychaeta, Polynoidae) from Vietnam
}

\author{
Temir A. Britayev', Kristian Fauchald ${ }^{2}$
}

\begin{abstract}
${ }^{1}$ A.N. Severtzov Institute of Ecology and Evolution Russian Academy of Sciences, Leninsky pr. 33, 117071 Moscow, Russia.e-mail:temir@invert.sevin.msk.ru

${ }^{2}$ Department of Zoology, National Museum of Natural History, Smithsonian Institution, P.O. Box 37012, NHB MRC 0163, Washington, DC 20013-7012,USA. e-mail: Fauchald@si.edu
\end{abstract}

ABSTRACT: During the observation of fauna associated with starfishes performed at the shallow coastal waters of Vietnam (South China Sea, Nhatrang Bay) in 1985, 1987, 1988 and 1999, the new species of symbiotic scaleworm was found. The species is similar to Asterophilia carlae, but differs in elytra with distinctive frontal pockets and micropapillae, and in middle neurochaetae with serrated edge and without enlarged basal row of serrations (semilunar pocket). The specimens were associated with starfishes Culcita novaeguineae, Protoreaster nodosus, Linckia laevigata, and with unidentified unstalked crinoids. Worms have been located on the ventral surface of starfishes or hidden in ambulacral grooves. Each infested host harbored 1 or 2 specimens of scaleworm. The prevalence of host infestation was very low in all host species and counted in $C$. novaeguineae. It varied from $3.3 \%$ to $13 \%$ with average meaning $8.5 \%(\mathrm{n}=188)$. Females were slightly larger than males. This is the first record of Asterophilia species at the coast of Vietnam and the first record of symbiotic polychaete associated with wide spread tropical starfish Culcita novaeguineae and the fifth symbiotic polychaetes recorded in Vietnamese coastal waters.

KEYWORDS: symbiosis, polychaetes, scaleworms, sea stars, Vietnam.

\section{Новый вид симбиотических чешуйчатых червей рода Asterophilia (Polychaeta, Polynoidae) из Вьетнама}

\section{Темир А. Бритаев ${ }^{1}$, Кристиан Фочалд²}

\begin{abstract}
${ }^{I}$ Институт проблем экологии и эволющчи им. А.Н. Северцуова Российской Академии наук, Ленинский пр. 33, 119071 Москва, Россия.e-mail: temir@invert.sevin.msk.ru

2 Департамент зоологии, Национальный Музей Естественной Истории, Институт Смитсона, n/я 37012, Вашингтон, США. e-mail: Fauchald@si.edu
\end{abstract}

РЕЗЮМЕ: В ходе исследования фауны, ассоциированной с морскими звездами у побережья Вьетнама, был найден новый вид чешуйчатых многощетинковых червей. Новый вид близок Asterophilia carlae, известного с побережья Фиджи и Индонезии, но отличается наличием на элитрах отчетливых фронтальных карманов и микропапилл и средними неврохетами с зазубренным краем, но без базальной зубчатости (кармана). Новый вид обитает на звездах Culcita novaeguineae, Protoreaster nodosus, Linckia laevigata и на не определенных морских бесстебельчатых лилиях. Симбионты были локализованы на вентральной поверхности звезд или прятались в их амбулакральных желобках. На каждом заселенном хозяине была 1-2 полихеты. Заселенность всех хозяев была очень низкой. Она подсчитана для звезды $C$. novaeguineae где колебалась от 3,3\% до 13\%, составляя в среднем 8,5\% (выборка 188 экз.). Самки были слегка крупнее самцов. Это первая находка представителей рода Asterophilia у побережья Вьетнама, первое сообщение о симбиозе полихет с широко распространенной тропической морской звездой C. novaeguineae и пятый вид симбиотических полихет, найденный в прибрежных водах Вьетнама.

КЛЮЧЕВЫЕ СЛОВА: симбиоз, полихеты, чешуйчатые многощетинковые черви, морские звезды, Вьетнам. 


\section{Introduction}

Symbiotic polychaetes are relatively rare, but invariable components of marine fauna (Martin, Britayev, 1998). The fraction of symbiotic species within the polychaete fauna may vary from area to area but is increasing in tropical waters. For instance, according to Gibbs (1969) in the littoral zone of Solomon Islands 12 species of symbiotic polychaetes has been found representing about $5.5 \%$ of the total polychaete species number. This is obviously higher than the $1.8 \%$ of symbionts currently known for all species of polychaetes (Martin, Britayev, 1998).

The fauna of symbiotic polychaetes of Vietnamese coast is poorly known. A review of the literature reveals 4 species recorded mainly from the vicinity of Nhatrang (Gallardo, 1967; Britayev, Zamyshliak 1996; Radashevsky, 1996; Lopez at al., 2001). This is substantially less than species number recorded for the littoral zone of Solomon Islands and comparable with the number of symbiotic scaleworms recorded from Hong Kong (Hanley, 1992). Taking into account the high level of biodiversity of South China Sea the expected number of symbiotic polychaetes from Vietnam has to be substantially higher.

The monotypic genus Asterophilia was established by Hanley (1989) for a new species of scaleworm with 15 pairs of elytra of which the last four pairs are attached on chaetigers 23, 26, 29 and 32, i.e. which is by far the most common arrangement. It was also very similar to Gastrolepidia clavigera Schmarda, 1861 which is very wide spread in tropical Pacific and Indian Oceans, in the morphology of prostomium, parapodia, and chaetae and in the presence of the unusually shaped antennae and dorsal cirri with inflated tips. Due to this similarity Asterophilia carlae Hanley, 1989 was confused with $G$. clavigera by Horst (1917) and overlooked for a long time (Hanley, 1989). A. carlae was described based on three specimens from two geographically rather distant localities, Fiji Islands and Gaspar Strait, Indonesia. It was associated with starfish Linckia laevigata (Linneus, 1758) at Fiji, and with an unidentified starfish in Indonesia. During fieldstudies of Vietnamese marine fauna performed by the first author in 1985-1990, 2003 and in 2004 , significant numbers of scaleworms associated with 3 species of starfishes and one species of crinoids were found. They were similar with $A$. carlae, but differed in some details. This material allowed us to describe the new species belonging to Asterophilia and to improve the generic diagnosis. Some data on the species ecology were obtained based on the method of sampling which could be characterized as semi-quantitative. This is the first record of representatives of Asterophilia at the coast of Vietnam and the first record of symbiotic polychaete associated with the widely dispersed coral predator starfish Culcita novaeguineae Muller et Troschel, 1842.

\section{Material and method}

Material was collected in Nhatrang Bay in southern Vietnam (Fig. 1). Hosts animals were sampled by SCUBA diving and snorkeling at 2-10 $\mathrm{m}$ depth. While still under the water hosts

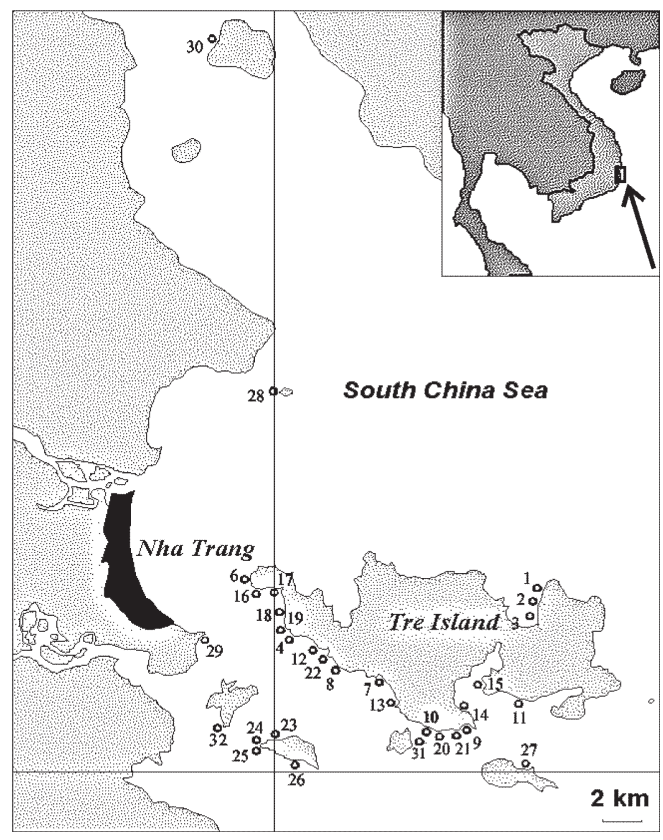

Fig. 1.Study area; circles indicate sampling localities. Рис. 1. Район исследований; кружками отмечены точки взятия проб. 
were put into plastic bags or wrapped in gauze, each specimen separately, to keep symbionts together with the host. On the boat, the starfish radius, the distance between the mouth and the end of starfish's arms were measured. Symbionts usually were located on the ventral surface of starfishes or hidden deep in their ambulacral grooves. For the extracting of scaleworms starfish were placed into closed plastic bags for 30-40 minutes, so that anoxic conditions developed. The lack of oxygen force symbionts to leave their shelter and make them accessible for collecting. In the laboratory, the length of worms and width at chaetigers $8-15$ were measured, and the number of chaetigers was counted under the binocular microscope. The sex of worms was determined after partial dissections of specimens and examination of fluid extract under the microscope. The drawings were prepared with a microscope with drawing tube. Scanning electron microscope (SEM) micrographs were made after critical point drying and coating with $300 \AA$ of gold, at the Laboratory of Electronic Microscopy, A.N. Severtzov Institute of Ecology and Evolution RAS. The specimens are deposited in Zoological Museum of Moscow State University (ZMMSU), Moscow, Russia.

\section{Results}

Family Polynoidae Malmgren, 1867 Subfamily Arctonoinae Hanley, 1989 Genus Asterophilia Hanley, 1989

Diagnosis. Body flattened, fusiform, fragile, up to 48 segments. Elytra 15 pairs, on prominent elytrophores, on segments $2,4,5,7$, $9,11,13,15,17,19,21,23,26,29$, and 32 ; this is by far the most common arrangement. Posterior segments cirrigerous without elytra. Elytra large, soft, transparent with or without micropapillae and with rounded macrotubercles. Prostomium bilobed, wider than long, without cephalic peaks. Two palps, three antennae present. Ceratophore of median antenna inserted in anterior notch, ceratophores of lateral antennae inserted terminoventrally on distal ends of prostomium. Tentaculophores lateral to the prostomium, achaetous, with two pairs of dorsal and ventral tentacular cirri. Buccal segment with small nuchal fold, buccal cirri (i.e., ventral cirri of chaetiger 2) longer than following ones. Proboscis with 11 pairs of papillae and 2 pairs of brown jaws. Parapodia biramous, notopodia small, subconical with long, slender acicular lobe. Neuropodia larger, deeply cut dorsally and ventrally, with longer prechaetal and shorter postchaetal lobes. Notochaetae short to long, slightly curved with rows of serrations and notched tips. Neurochaetae long; upper ones slender with subterminal swelling, rows of serrations and hooded, notched tips; middle and lower ones much stouter, with subterminal swelling and fewer rows of serrations, middle ones with bi- or unidentate tips, lower ones with few rows of serrations and curved unidentate tips. Dorsal cirri present on segments without elytra, cirrophores large, styles smooth, cylindrical basally, subdistal inflated with filiform tips; dorsal tubercles absent. Ventral cirri short, tapered. Anus terminal with long anal cirri. Symbiont with asteroids and crinoids.

Type species. Asterophilia carlae Hanley, 1989.

\section{Asterophilia culcitae sp. n.}

Figs. 2-4.

Type locality. Tam Island, Nhatrang Bay, Vietnam, South China Sea.

Material examined. Holotype: one specimen in alcohol (N 4512 ZMMSU), South China Sea, Nhatrang Bay, Tam Island, station 24, 3-5 m, 10 Feb. 1989, whole + with everted pharynx on C. novaeguineae.

Paratypes: six specimens in alcohol (N 4513-4518 ZMMSU), South China Sea, Nhatrang Bay. Mot Island, station 31, 28 May 2004, whole specimen without elytra on $C$. novaeguineae; Mieu Island, station 32, 14 May 2004, whole specimen on C. novaeguineae; Tre Island, station 4, 3-5 m, 23 May 2004, fragmented + and juv. on $C$. novaeguineae; Tam Island, station 23, 3-8 m, 5 Nov. 1985, fragmented + without posterior region and whole juv. on $C$. novaeguineae.

Other material: 22 specimens in alcohol, South China Sea, Nhatrang Bay. Tre Island, 


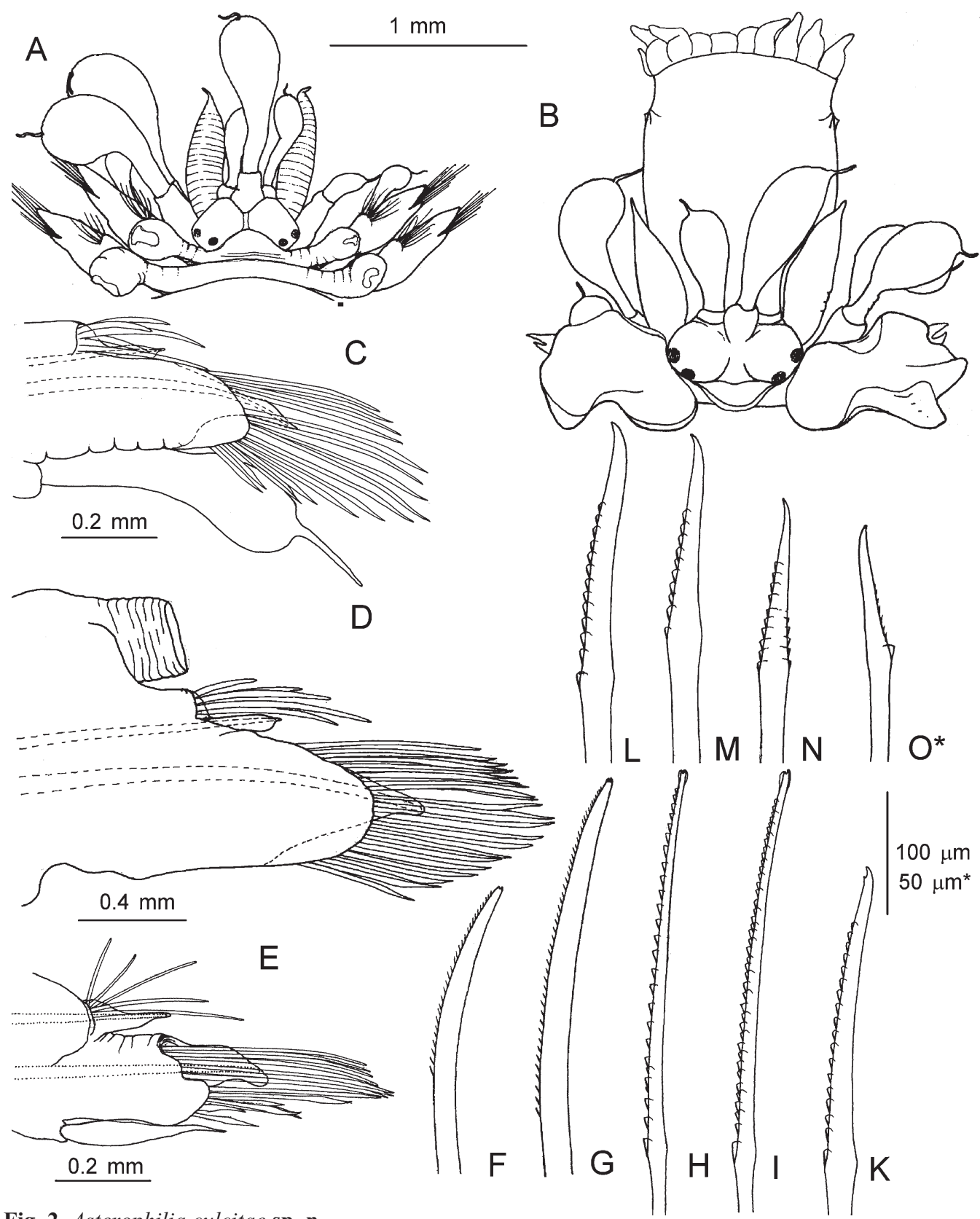

Fig. 2. Asterophilia culcitae sp. n.

A - anterior end, dorsal view; B - anterior end of holotype (ZMMSU 4512) with everted pharynx, dorsal view; C parapodium of chaetiger 2, posterior view; D - parapodium of chaetiger 10, posterior view; E - parapodium of chaetiger 40, posterior view; $\mathrm{F}-\mathrm{G}$ - notochaetae; $\mathrm{H}-\mathrm{I}$ - upper neurochaetae; $\mathrm{K}-\mathrm{L}$ - middle neurochaetae; $\mathrm{M}-\mathrm{N}$ lower neurochaetae; $\mathrm{O}$ - lower neurochaetae with semilunar pocket of juvenile specimens.

Pис. 2. Asterophilia culcitae sp. $\mathbf{n}$.

А — передний конец тела, вид сверху; В - передний конец тела голотипа (ЗММУ 4512) с вывернутой глоткой, вид сверху; С - параподия 2-го щетинкового сегмента, вид сзади; D - параподия 10-го щетинкового сегмента, вид сзади; Е - параподия 40-го щетинкового сегмента, вид сзади; F-G - верхние нотохеты; H-I - верхние неврохеты; $\mathrm{K}-\mathrm{L}$ - средние неврохеты; M-N - нижние неврохеты; O - ювенильный экземпляр, нижняя неврохета с карманом. 
station 6, 4-6 m, 23 Nov. 1985, 1 o on $C$. novaeguineae; station 3, 1-3 m, 5 Dec. 1985, one juv. on starfish Culcita novaeguineae; station 4, 7-10 m, 9 Feb. 1989, $1 \sigma^{7}$ on Protoreaster nodosus (Linneus, 1758); station 6, 3-5 m, 14 Feb. 1989, one specimen on $C$. novaeguineae; station 12, 5-7 m, 14 Mar. 1989, 4 specimens ( 2 couples) on C. novaeguineae; station 12, 5-7 m, 11 June 1990, 1 on $C$. novaeguineae; station 10, 4-6 m, 30 Jul. 1990, two specimen on C. novaeguineae; station 10, 4-6 m, 22 Aug. 1990, 1 on C. novaeguineae; Tam Island, station 25, 7-10 m, 20 Feb. 1987, $1 \mathrm{O}^{7}$ on C. novaeguineae; station $24,3-5 \mathrm{~m}, 10$ Feb. 1989, $1 \sigma^{7}$ and 1 on C. novaeguineae; station 25, 4-6 m, 17 Feb. 1989, one specimen on C. novaeguineae; station 26, 4-6 m, 18 Feb. 1989, 2 90 on C. novaeguineae; station 24, 3$5 \mathrm{~m}, 15$ Mar. 1989, 1 + on C. novaeguineae; station 25, 4-6 m, 10 Oct. 2003, one specimen on Linckia laevigata; to the North of the seaport of Nhatrang, station 29, 2-4 m, 25 Jan. 1987,1 on C. novaeguineae; Nha Trang Bay, 5-6 m, 10 Mar. 1986, 2 우 on unidentified crinoids.

Description. Body truncate anteriorly and tapering posteriorly, flattened dorsally and ventrally, very fragile, with 15 pairs of elytra, with up to 48 segments, $0.6-2.3 \mathrm{~mm}$ wide without parapodia, 5.5-23 mm long.

Prostomium bilobed, wider than long, without cephalic peaks; median notch a Vshaped gap between anterior ends of superior prostomial lobes, filled by median ceratophore, prostomial lobes completely separated by distinctive groove, its anterolateral parts rounded or inflated (Figs. 2A,B; 3C; 4A). Two pairs of brown eyes, ovate or round in shape, equal in size or posterior pair slightly smaller; anterior pair located dorsolaterally at widest part of prostomium, positioned laterally, oriented antero-laterally; posterior pair on the rear margin of prostomium, oriented dorsally; eyes of a pair (i.e. anterior or posterior) separated by at least one eye-diameter. Median antenna 1.5-2 times longer than lateral ones, 3-4 times longer than prostomium, inserted anteriorly in median notch, all antennae inflated subdistally with short fili- form tips, not papillated. Lateral antennae inserted ventral to dorsal prostomial lobes and slightly ventral to median antenna, with slender ceratophores, separated by groove from prostomium. Palps stout, longer or the same in length as lateral antennae and shorter than median one, without subdistal inflation, with distinct separation between palpophore and style, not papillated (Fig. 2A,B).

First segment not visible dorsally, tentaculophores long, achaetous, but with aciculae; two pairs of tentacular cirri, all subdistally inflated, with filiform tips and not papillated, dorsal and ventral tentacular cirri similar in length or dorsal slightly longer than ventral, (Fig. 2A,B). Pharynx with 11 dorsal and 11 ventral large terminal papillae, 2 lateral pairs are smaller than others, in addition two pairs of small lateral papillae (Fig. 2B); with 2 pairs of brown jaws. Mouth surrounded by two lateral, ventral and dorsal lips; median (upper) lip with distinctive wide median ridge (Fig. 3D); facial tubercle absent. Segment 2 with semilunar nuchal fold covering posterior part of prostomium (Figs. 2A,B; 3C; 4A) with biramous parapodia and one pair of buccal cirri as long as ventral tentacular cirri or shorter; with subdistal inflation and filiform tip (Figs. 2A; 3D).

Elytra number 15 pairs on chaetigers 2, 4, 5,7 , continuing on alternate segments to 23 ; last three pairs on 26, 29 and 32 at all specimens. Posterior 3-15 chaetigers cirrigerous without elytra. Elytra large, soft, overlapping medially and posteriorly, covering body completely; with distinct frontal pockets; with a scattering of minute papillae and three, rarely 2 or 4 raised pigmented round mounds (macrotubercles) along posterior edge, posterior margin of elytra slightly folded, (Fig. 3E,F).

Dorsal tubercles absent. Dorsum of body segments with two transverse ciliary bands per segment connecting the bases of cirrophores or elytrophores (Fig. 4A); numerous ciliary bundles are located on the basal part of parapodia (Fig. 4C).

Parapodia biramous (Figs. 2C-F; 4B). Notopodia small, located on parapodial anterodorsal face, with conical acicular digitiform 
lobes, aciculae penetrating surface; notochaetae present (Figs. 2C-F; 4B). Dorsal cirri attached to posterodorsal face of neuropodia; cirrophores distinctly shorter than cirrostyles, conical; styles as long as parapodia with subdistal inflation and short filiform tips; without distinct papillae, cirri emerge through frontal pockets of elytra of next following segment; similar in length in all cirrigerous chaetigers. Last few segments with dorsal cirri as well developed as in preceding chaetigers.

Neuropodia much larger, with long subtriangular prechaetal lobe, digitiform acicular lobe, and shorter postchaetal lobe with rounded tip; aciculae penetrating surface of acicular lobe (Fig. 2C-E).

Notochaetae arising mainly dorso-laterally from the notopodia, very few, 3-14 in a bundle above acicula, as thick as neurochaetae, round in cross-section, straight or gently curved with short marginal serrations and slightly notched tips (Fig. 2F,G).

Neurochaetae numerous, 24-34 per bundle; upper neurochaetae long, straight, slender, with 22-24 rows of serrations and notched, hooded tips (Fig. 2H,I); middle neurochaetae with relatively shorter serrated part and uni- or bidentate tips (Fig. 2K,L); lower neurochaetae stout, shorter, with few rows of serrations (up 8-9) and slightly curved unidentate tips (Fig. $2 \mathrm{M}, \mathrm{N})$. Neurochaetae with an enlarged basal row of serration characteristic for $A$. carlae (resembling the semilunar pockets of Adyte) absent in most specimens; found only in one juvenile specimen (Fig. 2O).

Ventral cirri from the 3rd chaetiger to the end of the body short, gradually tapering (Fig. 2E). Pygidium with 2 large inflated cirri.

Coloration and mimicry. The color patterns of worms alive are in accordance with the basal coloration of respective hosts, bluish in worms associated with Linckia laevigata and reddish in Culcita novaeguineae associates (Fig. 3A,B). Moreover, the antennae, tentacular and dorsal cirri of the worm with their subdistal swellings and the pigmented mounds on the elytrae mimic perfectly tube feet and spicules of starfish hosts hiding the worms from predators.
Elytra of worms preserved in alcohol transparent, brownish, with 3 (2-4) whitish or yellowish opaque spots on their posterior part (Fig. 3E), sometimes with thin brown rim along posterior margin. Micropapillae are dark-brown in transmitted light (Fig. 3F) and look like small light spots in the reflected light. Body in some specimens with distinct pigment pattern: transverse brownish pigmented band crossing dorsal surface of each segment and two lightcolored narrow ciliary bands joining at the base of cirrophores or elytrophores. Brownish bands are longer on the cirrigerous segments rising on the bases of cirrophores, and relatively shorter on elytraegerous segments. Pigmentation of other specimens may be more intense: dorsal surface with dark brown pigmentation which masks the pigmented pattern; ventral surface, distal part of parapodia and elytrophores slightly lighter in color. In all specimens subdistal inflations of antennae, tentacular and dorsal cirri lighter than the body, light-yellow or milky-white.

Etymology. Referring to the most common host species in the studied area, the cushion starfish Culcita novaeguineae.

Distribution. Nhatrang Bay, Vietnam.

Remarks and differential diagnosis. In his description of Asterophilia carlae Hanley (1989) used specimens from two distant localities: Mana Western, Fiji (holotype) and the Gaspar Strait, Indonesia. According to figures presented in Hanley's paper enlarged basal row of serrations in lower neurochaetae is characteristic for specimen from Fiji, but not from Gaspar Strait. In this respect the latter resemble the Vietnamese specimens. Our specimens from Nhatrang differ from holotype of $A$. carlae in several small features: (1) elytra with distinct frontal pockets instead of anterior fold, and (2) with micropapillae, which were not mentioned in description of $A$. carlae, (3) middle and lower neurochaetae with serrated edge and without enlarged basal row of serrations (semilunar pocket) characteristic for holotype.

Biology. Symbiont of starfishes Culcita novaeguineae, Protoreaster nodosus and Linckia laevigata; in addition two specimens have been found in the same area associated with 


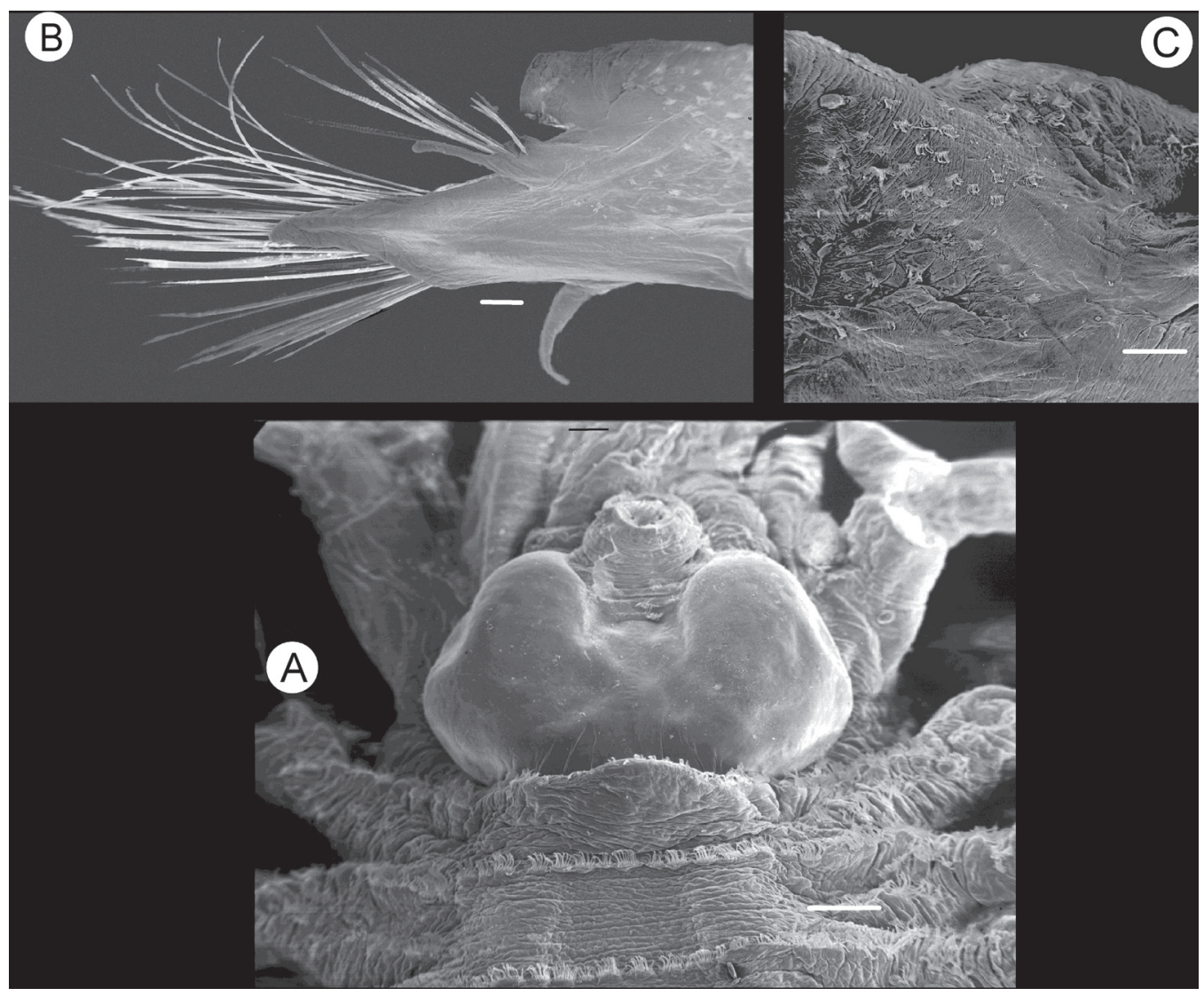

Fig. 4. Asterophilia culcitae sp. n., SEM micrographs: A - dorsal view of anterior end showing transversal ciliary bands; $\mathrm{B}$ - parapodium of $8^{\text {th }}$ chaetiger, anterior view; $\mathrm{C}$ - dorsal surface of the same parapodium magnified, with groups of cilia. Scale bar $=100 \mu \mathrm{m}$.

Рис. 4. Asterophilia culcitae sp. n., СЭМ микрофотографии: А - передний конец тела, вид сверху; видны поперечные ресничные полоски; В - параподия 8-го щетинкового сегмента, вид спереди; Сдорсальная поверхность параподии, увеличено; видны группы ресничек. Масштаб = 100 мкм.

unidentified unstalked crinoids by Dr. V.I. Radashevsky. Worms have been located on the ventral surface of starfishes or hidden in ambulacral grooves. The prevalence of host infestation was very low in both host species and was calculated for $C$. novaeguineae. It varied from year to year and was $3.3 \%(\mathrm{n}=60 \mathrm{sp}$.) in Nov.Dec.1985, 9.5\% ( $\mathrm{n}=21$ sp.) in Jan. - Feb. 1987, 10.3\% ( $\mathrm{n}=87$ sp.) in Feb. - Mar. 1989, $13 \%(\mathrm{n}=23 \mathrm{sp}$.$) in Jun. - Aug. 1990. The real$ prevalence of $C$. novaeguineae may actually be higher since worms are able to hide in the deep ambulacral grooves of starfish, making retrieval difficult. Each infested host harbored from 1 to 2 worms, but infestation by pairs of worms was rare $(22.2 \%)$ and the presence of a single symbiont dominated $(77.8 \%)$. Thus, Asterophilia culcitae showed a characteristic regular pattern inside cushion-starfish hosts. Three of four pairs consisted of a male and a female indicating pair formation on a host. Pair formation in Asterophilia culcitae seems to be temporal, as supported by the low frequency of pairs compared to other symbiotic polychaetes (e.g. Ruff, 1991; Martin et al., 1992; Britayev, Zamyshliak, 1996). Mean width of females and males were $1.66 \mathrm{~mm}(\mathrm{n}=8 \mathrm{sp}$.) and $1.33 \mathrm{~mm}(\mathrm{n}$ $=6 \mathrm{sp}$.) respectively, i.e. females are slightly 
larger than the males. Many specimens have damaged or regenerating elytra, cirri, parapodia and posterior end of body, suggesting either frequent intraspecific fighting or attacks by predators. Associated species on C. novaeguineae: pontoniin shrimp Periclimenes soror, two undescribed species of scaleworms belonging to the genus Hololepidella and the carapid fish Carapus mourlani. Worms were collected in 3 to $10 \mathrm{~m}$ depth.

\section{Acknowledgements}

We are thankful to O.V. Savinkin for the color photos of Aterophilia culcitae and valuable help with collecting the material, to Tatiana Antohina for preparing SEM photos and for Dr. D. Martin for the help with drawings arrangement, V.I. Radashevsky for the specimens of scaleworms associated with crinoids. This study was supported by the Russian-Vietnamese Tropical Research and Technological Centre, by the Federal Program "World Ocean. The studies of World Ocean nature, the dynamic of ecosystems" of the Russian Ministry of Sciences and Technologies and by the Russian Foundation for Basic Research (Grant 05-04-48350).

\section{Literature}

Britayev T.A., Zamyshliak E.A. 1996. Association of the commensal scaleworm Gastrolepidia clavigera(Polychaeta: Polynoidae) with holothurians near the coast of South Vietnam // Ophelia. Vol.45. P.175-190.
Gallardo V.A. 1967. Polychaeta from the bay of Nha Trag, South Viet Nam // Scientific Researches on the Marine Invertebrates of South China Sea and the Gulf of Thailand, 1959-1961. NAGA report. Vol.4. P.35279.

Gibbs P.E. 1969. Aspects of polychaete ecology with particular reference to commensalism// Philosophical Transactions of the Royal Society of London. Vol.255. P.443-458.

Hanley J.R. 1989. Revision of the scaleworm genera Arctonoe Chamberlin and Gastrolepidia Schmarda (Polychaeta, Polynoidae) with the erection of a new subfamily, Arctonoinae // The Beagle, Records of the Northern territory Museum of Arts and Sciences. Vol.6. P.1-34.

Hanley J.R. 1992. Checklist of scaleworms (Polychaeta: Polynoidae) from Hong Kong // B. Morton (ed.). The marine flora and fauna of Hong Kong and southern China. Proceedings of the Fourth International Marine Biological Workshop. Hong Kong: Hong Kong University Press. P.361-369.

Horst R. 1917. Polychaeta Errantia of the Siboga Expeditions. Pt. 2 Aphroditidae and Chrysopetalidae // Siboga Expeditie, Monographie. Bd.24: 140 p.

Lopez E., Britayev T.A., Martin D., San Martin G. 2001. New symbiotic associations involving Syllidae (Annelida: Polychaeta), with taxonomic and biological remarks on Pionosyllis magnifica and Syllis cf. armillaris // J. Mar. Biol. Ass. U.K. Vol.81. P.399-409.

Martin D., Rosell D., Uriz M.J. 1992. Harmothoe hyalonemae sp. nov. (Polychaeta, Polynoidae), an exchusive inhabitant of different Atlanto-Mediterranean species of Hyalonema (Porifera, Hexactinellida) // Ophelia. Vol.35. P.169-185.

Radashevsky V.I. 1996. Morphology, ecology and asexual reproduction of a new Polydorella species (Polychaeta: Spionidae) from the South China Sea // Bulletin of Marine Science. Vol.58. P.684-693.

Ruff R.E. 1991. A new species of Bathynoe (Polychaeta: Polynoidae) from the Northeast Pacific Ocean commensal with two species of deep-water asteroids // Ophelia. Vol.5. P.219-230. 


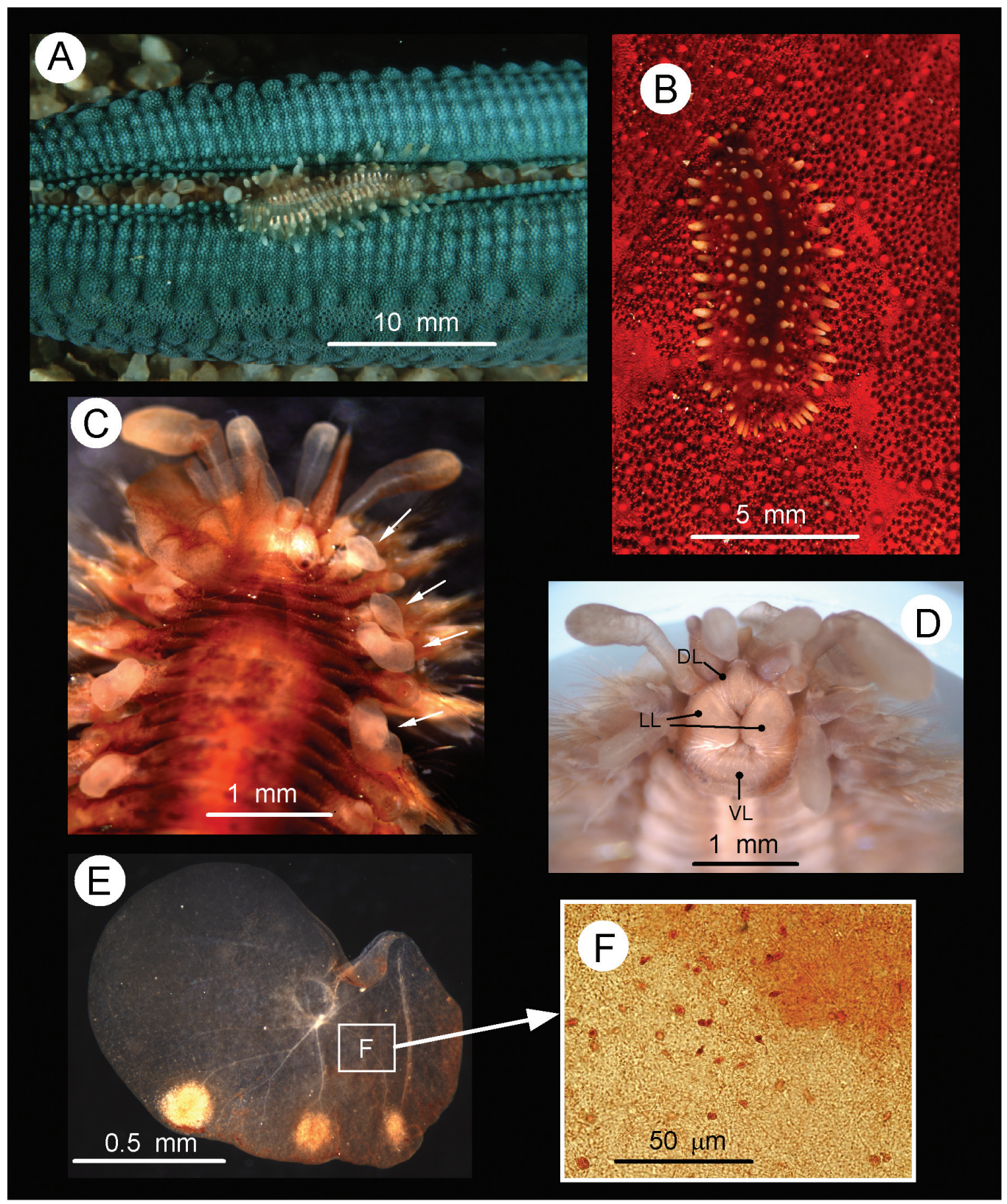

Fig. 3. Asterophilia culcitae sp. n.: A — photo in situ on the arm of starfish Linckia laevigata; B — photo in situ on the surface of starfish Culcita novaeguineae; $\mathrm{C}$ - anterior end, dorsal view, regenerated elytra indicated by arrows; D - anterior end of paratype, terminal view; E - elytron; F — detail of the elytron structure with micropapillae. DL — dorsal lip; LL — lateral lips; VL — ventral lip.

Pис. 3. Asterophilia culcitae sp. n.: А — фотография in situ на луче морской звезды Linckia laevigata; $\mathrm{B}$ - фотография in situ на поверхности морской звезды Culcita novaeguineae; C - передний конец тела, вид сверху, регенерирующие элитры отмечены стрелками; D — передний конец тела паратипа, вид спереди; Е — элитра; F — детали строения элитры, видны микропапиллы. DL — верхняя губа; $\mathrm{LL}$ - боковые губы; VL — нижняя губа. 